\title{
Research on Credit System Construction of Small and Medium-Sized Enterprises
}

\author{
Ling XIN, Jie YANG \\ School of Economics, Hebei Polytechnic University, Tangshan, Hebei Province, 063000, China \\ 462611460@qq.com, xinling89513@163.com
}

mobile: 13613155289

\begin{abstract}
Small and Medium-sized Enterprises (SME) is the major driving force for the economic development of China, but financing difficulties are impeding their smooth development. Therefore, enhancing the construction of credit system is of great importance for solving the problem. In this essay, we firstly analyze the connotation and meaning of enterprises' credit system, and then illustrate the current status and reasons for the lack of credit of SME, and finally propose the countermeasures of improving the credit system of SME.
\end{abstract}

KEYWORD: credit system; financing guarantee; credit rating

\section{INTRODUCTION}

SME is the major driving force of our economic development, and it accounts for $99 \%$ of the whole enterprises in China, $60 \%$ of GDP and tax revenue, $70 \%$ of employees and technological creations, and it plays a significant role in stimulating economy, enhancing employment and improving innovation. However, owing to the imperfection of credit system and information asymmetry in terms of internal information, solvency and project risks between SME and banks, SME has difficulties applying for loans since banks do not have clear opinion about their future development and the risk of not paying the debt. Now, the commercial banks' reject rate for SME's loan is about $50 \%$ and only $15 \%$ of SME can have direct financing from banks. Therefore, enhancing the construction of SME's credit system is important for solving the financing problem.

\section{CONNOTATION AND MEANING OF ENTERPRISES' CREDIT PREPARING}

Credit is a temporary transfer between creditor and debtor about commodity, capital and service, a special form for value activity under market-oriented economy, and the credit activity of payment and repayment. Credit activity can be divided into personal credit, enterprise credit and government credit. Enterprise credit should be paid much attention for its importance in economic activities.

In economic activities, enterprise credit is like the name card of this enterprise and is the key point for achieving bank loans, exploiting the market and improving the operation. Laking of great credit may result in the obstacle for SME of living in the market, and even breaking down.

\section{BEHAVIOR AND REASONS OF CREDIT DEFICIENCY OF SME}

\subsection{Behavior of Credit Deficiency}

With the improvement of our macro economy environment and legal rules, the awareness of honest operation of SME has been strengthened. Overall, the construction of credit system is still imperfect, which shows as follows:

\subsubsection{Productive Credit Deficiency}

It includes hiding the facts and making frauds to consumers to earn profits. In addition, many SME do not have strict quality management system and certification, use bad raw materials and illegal production, which are not known by the consumers.

\subsubsection{Financial Credit Deficiency}

Many SME are providing fake financial reports in order to avoid tax with audit institutions to complicit in making fake financial data. Some enterprises are seeking profits by opening subsidiary companies and various banking accounts. 


\subsubsection{Commercial Credit Deficiency}

In order to saving costs and stimulating production, some SME use credit transaction forms like credit agreement, authorization, contracts and guarantee. However, it shows that there are a lot of defaults behind the credit transactions. According to the analysis, only $70 \%$ of contracts are being fulfilled and about 5.5 billion RMB has been paid as the loss for contract fraud, 300 billion RMB existed as default, and 200 billion RMB is the financial fees for chain debt and fault for cash payment.

\subsubsection{Financing Credit Deficiency}

Some SME pay little attention to the construction of credit system and some have bad debt repayment ability and high credit risk, which makes banks reluctant to lend money to them. According to the powerful research, $23.5 \%$ of the SME which did not get the loan have bad records of not paying back the loan interest or being asked to repay the loan. In 2012, 40,000 restructuring SMEs have been researched by the SME Credit Department of Industrial and Commercial Bank of China, and based on the research results, black-list enterprises' loan capital accounts for about $40 \%$, which has a big effect on the financial institutions' enthusiasm for making loan to SME.

\subsection{Reasons for Credit Deficiency}

\subsubsection{The Demand for Improvement of Self-quality of $S M E$}

Firstly, the internal structure of SME is deficient that ownership and management are not separated completely in the operating structure, and that the lack of counterbalance between owner and manager, the lack of protection for small and medium shareholders exist in it. Secondly, financial policies have problems in terms of internal financial management regulations, lower capital turnover rate, necessary internal control and financial employees not competent for the job. Thirdly, there are higher operational risks, such as lower profits, higher assets-debt ratio, higher financial fees, which results in default for repayment of bank loans.

\subsubsection{Information Asymmetry between Enterprises and Banks}

Banks' loan business are mainly based on the enterprises' financial and operational information, but most SME do not have standard financial system, talented financial employees and standard financial reports, which cause SME higher financial fees compared with big companies fir using fund. And higher financial fees have been a major obstacle for financing. According to analysis of 3.34321 billion SMEs (independent accounting)'economic files, the average main business income, paid-up capital and financial fees are 5446.27 million RMB, 878.5824 million RMB and 52.1062 million RMB separately, accounts for $60.7 \%, 58.6 \%$ and $58.4 \%$ of the whole industrial enterprises' average numbers of the current year. And according to the above data, even though the scale and revenue of SME is increasingly increased, financial fees of financing caused by the irregular financial structure are much higher than that of big companies. Higher financial fees have become the obstacle of SME's financing. (Table 1)

Table1 The analysis of SME in 2012 industrial economic

\begin{tabular}{|c|c|c|c|}
\hline \multirow{2}{*}{ Subject } & \multicolumn{3}{|c|}{ Content } \\
\cline { 2 - 4 } & $\begin{array}{c}\text { Paid-up } \\
\text { capital }\end{array}$ & $\begin{array}{c}\text { Main } \\
\text { business } \\
\text { income }\end{array}$ & $\begin{array}{c}\text { Financial } \\
\text { fees }\end{array}$ \\
\hline $\begin{array}{c}\text { Big } \\
\text { companies }\end{array}$ & 568.2589 & 3846.6451 & 37.0283 \\
\hline SME & 878.5824 & 5446.27 & 52.1062 \\
\hline Comparison & $60.7 \%$ & $58.6 \%$ & $58.4 \%$ \\
\hline
\end{tabular}

data unit: million RMB

sources:012 yearbook of National Bureau of Statistics of China

\section{COUNTERMEASURES ON IMPROVEMENT OF CREDIT SYSTEM OF SME}

\subsection{Development of External Credit Rating System of SME}

To begin with, strengthening policies support and encouraging external rating business. External rating system can effectively improve information transparency, help local government and banks select better companies. Besides, through credit rating, enterprises can find existed problems and solve them. Therefore, government should positively support and encourage the external credit rating system business. In addition, cooperating with financial institutions and expanding the use of credit rating are of great importance. It should carry out assessment activities for grown-up enterprises, cooperate with banks, recommend qualified guarantee institutions and investment institutions, provide support for the long-run project and strengthen the ability of guarantee and investment institutions.

\subsection{Construction of Credit Investigation System of SME}

First, cultivate credit service market of SME means that guarantee companies' information should be added to the credit investigation system, credit information searching service should be provided to the guarantee institutions and risk control abilities should be improved. In addition, cultivating and 
developing credit investigation service institutions, publicizing related credit investigation knowledge, and improving the credit awareness. Second, exploding appropriate credit rating methods means that it should take simple and appropriate rating technology and value the credit situation and then make related credit decision and risk management. Finally, expanding the credit records, building the information data base, and taking credit records as the identification recognition and put the information into the database should be the focus.

\subsection{Improvement Financing Credit Guarantee System of SME}

Firstly, it should provide policy and capital support for guarantee company. Financial capital is the major source of credit guarantee institutions' fund and credit guarantee fund' $s$ activation and compensation fund, as well as get fund from financial institutions, enterprises to restructure the power of guarantee company. Guarantee fund should focus on improve employment and technological innovation project. The government should make clear regulations on the risk prevention, loss sharing system, encouragement policies, government supervision and should guide guarantee business to provide better service for SME. Secondly, guarantee running mechanism should be improved that guarantee risk sharing system be built to make appropriate guarantee ratio between guarantee institutions and banks to control risks and make financing successful. Besides, re-guarantee system should be developed to improve credit investigation, supervision and integration. Therefore, construction of re-guarantee system is of significant importance of building credit system.

\subsection{Improvement of Credit Legal System of SME}

Firstly, credit investigation legal system should be paid much attention that great information sharing system can not only optimize the allocation of resources, but also supervise and encourage the honesty of SME, as well as make punishment for those without credit. Secondly, credit guarantee legal system should be built, which is an important way to realize the creditor's right, that can stimulate the credit guarantee business. Thirdly, construction of credit supervision legal system means that the government should supervise those institutions providing credit service (including assessment, investigation and guarantee service), and make international standards for enterprises credit in order to protect creditors.

\section{CONCLUSION}

Difficulty in financing of SME is an urgent issue that need to be solved. Within the traditional credit market, credit lever has always been titled to big companies due to banks' rule of prudent lending. Therefore, SME has little chance of getting direct loan for the bank. And with the changing of national macro-economy, credit strategy of future banks will turn to focus more on SME.

Construction of credit system of SME is not only the market choice, but also the support from government. As for credit guarantee, credit assessment, investigation system and related legal system, government should cooperate with the market to build and improve the credit system od SME, as well as solve the financing difficulties and stimulate the healthy development of SME.

\section{REFERENCES}

[1] Kaisheng Yang, Support For Small And Medium-sized Enterprises Is The Inevitable Choice For Bank Development, Financial Times, 2011.3.12

[2] Boxin Gong, Analysis On The Effect Of Investigation System For Small And Medium-sized Enterprises, Shanghai Finance, 2008.10, P92-95

[3] Jiwei Yuan, Effect Of Credit Rating On The Financing Of Small And Medium-sized Enterprises,Time Financials, 2008.1, P55-57

[4] Xiaolin Liu, Researches On Financing Difficulties Of Small And Medium-sized Enterprises, Communication of Finance and Accounting,2011(2)

[5] Xiaomin Lai, Policy-thinking On Relief of Financing Difficulties of Small And Medium-sized Enterprises, China Financials, 2009(2), P61-63

[6] Ling Xin, a teacher from Hebei Polytechnic University, mobile: 13613155289 